\title{
Systematic Review \\ Measurement Methods of Fatigue, Sleepiness, and Sleep Behaviour Aboard Ships: A Systematic Review
}

\author{
Fiona Kerkamm ${ }^{1}$ (D), Dorothee Dengler ${ }^{1}$, Matthias Eichler ${ }^{1}$, Danuta Materzok-Köppen ${ }^{1}$, Lukas Belz ${ }^{1}$, \\ Felix Alexander Neumann ${ }^{2}{ }^{-}$, Birgit Christiane Zyriax ${ }^{2}$, Volker Harth ${ }^{1}$ and Marcus Oldenburg ${ }^{1, *}$ \\ 1 Institute for Occupational and Maritime Medicine Hamburg (ZfAM), University Medical Center \\ Hamburg-Eppendorf (UKE), 20459 Hamburg, Germany; fiona.kerkamm@web.de (F.K.); \\ dorothee.dengler@justiz.hamburg.de (D.D.); mail@dreichler.de (M.E.); \\ danuta.materzok@atem-balance.de (D.M.-K.); lukas.belz@justiz.hamburg.de (L.B.); \\ volker.harth@justiz.hamburg.de (V.H.) \\ 2 Midwifery Science-Health Services Research and Prevention, Institute for Health Services Research in \\ Dermatology and Nursing (IVDP), University Medical Center Hamburg-Eppendorf (UKE), \\ 20246 Hamburg, Germany; Fe.neumann@uke.de (F.A.N.); b.zyriax@uke.de (B.C.Z.) \\ * Correspondence: marcus.oldenburg@justiz.hamburg.de; Tel.: +49-40-428-374-308
}

Citation: Kerkamm, F.; Dengler, D.; Eichler, M.; Materzok-Köppen, D.;

Belz, L.; Neumann, F.A.; Zyriax, B.C.; Harth, V.; Oldenburg, M.

Measurement Methods of Fatigue, Sleepiness, and Sleep Behaviour Aboard Ships: A Systematic Review. Int. J. Environ. Res. Public Health 2022, 19, 120. https://doi.org/10.3390/ ijerph19010120

Academic Editors: Juan A. Moriano and Ana Laguía

Received: 20 November 2021

Accepted: 20 December 2021

Published: 23 December 2021

Publisher's Note: MDPI stays neutral with regard to jurisdictional claims in published maps and institutional affiliations.

Copyright: (C) 2021 by the authors. Licensee MDPI, Basel, Switzerland. This article is an open access article distributed under the terms and conditions of the Creative Commons Attribution (CC BY) license (https:// creativecommons.org/licenses/by/ $4.0 /)$.

\begin{abstract}
Since seafarers are known to be exposed to numerous job-related stress factors that can cause fatigue, sleepiness, and disturbed sleep behaviour, the aim of this review was to provide an overview of the subjective and objective measurement methods of these strains. Using a systematic review, 166 studies were identified within the period of January 2010 to December 2020 using the PubMed database. Of the 21 studies selected, 13 used both subjective and objective measurement methods. Six studies used only subjective and two studies only objective methods. For subjective assessment, 12 different questionnaires could be identified as well as activity and sleeping logs. Actigraphy and reaction time tests (RTT) were the most common objective methods. In single cases, electrooculography (EOG), pupillometry and ambulatory polysomnography (PSG) were used. Measurement-related limitations due to vessel-related impacts were less often reported than expected. No restrictions of daily routines on board were described, and only single-measurement disturbances due to ship movements were mentioned. The present literature review reveals that there are various routines to measure fatigue, sleepiness, and sleep behaviour on board. A combination of subjective and objective methods often appears to be beneficial. The frequent use of actigraphy and RTT on board suggests good feasibility and reliable measurements with these methods. The use of ambulatory PSG in maritime-like contexts suggests that this method would also be feasible on board.
\end{abstract}

Keywords: actigraphy; fatigue; measurement method; polysomnography; pupillometry; seafaring; sleep; sleepiness

\section{Introduction}

Seafarers are often exposed to psychophysical stress due to isolation, separation from family, time pressure, and long working days. In addition, noise from ship operations, vibration from the engine, and weather-related ship motion are other significant stressors that can reduce sleep quality on board [1]. Moreover, $91.6 \%$ of seafarers stated that they are frequently disturbed by at least one environmental factor, such as excessively cold or warm ambient temperatures, odours, noise, poor bedding conditions, or ambient light when sleeping in their cabins [2]. Noise was the most frequently mentioned disturbing stressor in relation to sleep, with $62.4 \%$ of seafarers complaining, followed by ambient temperature $(57.3 \%)$.

Overall, the causes of fatigue, sleepiness, and disturbed sleep on board are varied. The International Maritime Organization (IMO) [3] defines fatigue as a psychophysical consequence of a stressful situation typical of shipping that can negatively affect ship safety. The effects of fatigue are said to be manifested, for example, in reduced attention and 
memory, lowered responsiveness, increased risk-taking, and reduced problem-solving ability [3]. Fatigue and sleepiness can thus increase the risk of accidents at sea. In line with that, an analysis of 44 Incident at Sea Reports (with human errors as contributing factor) found that $86 \%$ of the analysed accidents had references to sleep-most of these $(34 \%)$ were connected to "sleep loss as a way of life" (waking at odd hours, daytime sleep, working instead of sleeping, and sleep hygiene factors) [4]. A review of additional 279 maritime accidents showed that fatigue contributed to $16 \%$ of critical ship incidents and $33 \%$ of personnel injuries [5].

Some of the ship's personnel (particularly the nautical officers and watchkeeping crew deck ranks) work 24-h shifts. These alternating day/night shifts cause disturbances of the circadian rhythm. Shift systems, such as the 6:6 and 4:8 shift system, only allow short interruptions in work for recovery and sleep phases. In the case of the 6:6 system, a watchkeeper works for six hours and then has six hours of free time-in constant rotation with the second watchkeeper. Shift changes usually take place at 6:00 a.m., 12:00 p.m., 6:00 p.m., and midnight. During the 4:8 system, three nautical officers take turns, each working four hours, followed by an eight-hour rest period. Shift changes occur at 4:00 a.m., 8:00 a.m., 12:00 p.m., 4:00 p.m., 8:00 p.m., and midnight. Especially during night work of the $6: 6$ system (midnight to 6 a.m.), increased sleepiness and shorter sleep episodes could be found on board ships [6].

While a variety of subjective and objective methods for measuring sleepiness exists, the determination of fatigue has so far been based only on subjective methods [7]. Even though sleepiness - unlike fatigue - can therefore be measured, e.g., using the Multiple Sleep Latency Test (MSLT), a clear definition and distinction between the terms fatigue and sleepiness is difficult, and therefore, these terms are often used interchangeably in publications [8]. Currently, there is a debate as to whether sleepiness can be considered a sub-component of fatigue [9] or whether the terms refer to two different constructs [10]. In the literature, sleepiness is often described as reduced central nervous activation, which can be attributed primarily to little or non-restorative sleep and has no correlation to psychological causes [11]. Fatigue, on the other hand, is described as a general feeling of subjective exhaustion and reduced performance, which can be caused by physical, psychological, and cognitive stress. However, unlike sleepiness, daytime sleep episodes are atypical in fatigue [11].

Overall, an objectifying survey of fatigue, sleepiness, and seafarers' sleep behaviour is an important component for seafarers' health and for the safety on board. Especially considering that fact, Allen et al. [12] concluded in their review "Seafarers' fatigue: a review of the recent literature" that the prevalence of fatigue in the maritime context appears to be higher than the seafaring industry is capable of or prepared to measure. Since a certain number of studies have already examined these strains using a wide variety of methods, this review aims to provide an overview of the objective and subjective measurement methods of fatigue, sleepiness, and sleep behaviour used on board. Furthermore, this work intends to provide support in the selection of measurement methods for future maritime studies.

\section{Materials and Methods}

As part of the interdisciplinary project "e-healthy ship" — which aims to optimise health management on board without the presence of doctors-a systematic literature search of maritime field studies covering the observation period from January 2010 to December 2020 was conducted using the PubMed database. Studies were independently screened for eligibility by three reviewers. Studies on fatigue or sleep in seafarers were identified using the following search terms or MeSHTerms (Medical Subject Headings): (sailor*[Title/Abstract] OR seafarer*[Title/Abstract] OR seamen[Title/Abstract] OR seaman [Title/Abstract] OR naval[Title/Abstract] OR ship[Title/Abstract] OR shipping[Title/Abstract] OR ships[Title/Abstract] OR maritime[Title/Abstract]) AND (OSA[Title/Abstract] OR 
apnoea*[Title/Abstract] OR sleep*[Title/Abstract] OR PSG[Title/Abstract] OR polysomno* [Title/Abstract] OR fatigue*[Title/Abstract]).

The search terms only included "seaman/-men" and not "seawoman/-women" due to the fact that female forms did not generate additional hits, as seafaring continues to be a male-dominated occupation.

This search string yielded a total of 166 hits during the above-mentioned observation period. Appropriate studies were selected according to the PRISMA (Preferred Reporting Items for Systematic Reviews and Meta-Analyses) statement (Figure 1) [13].

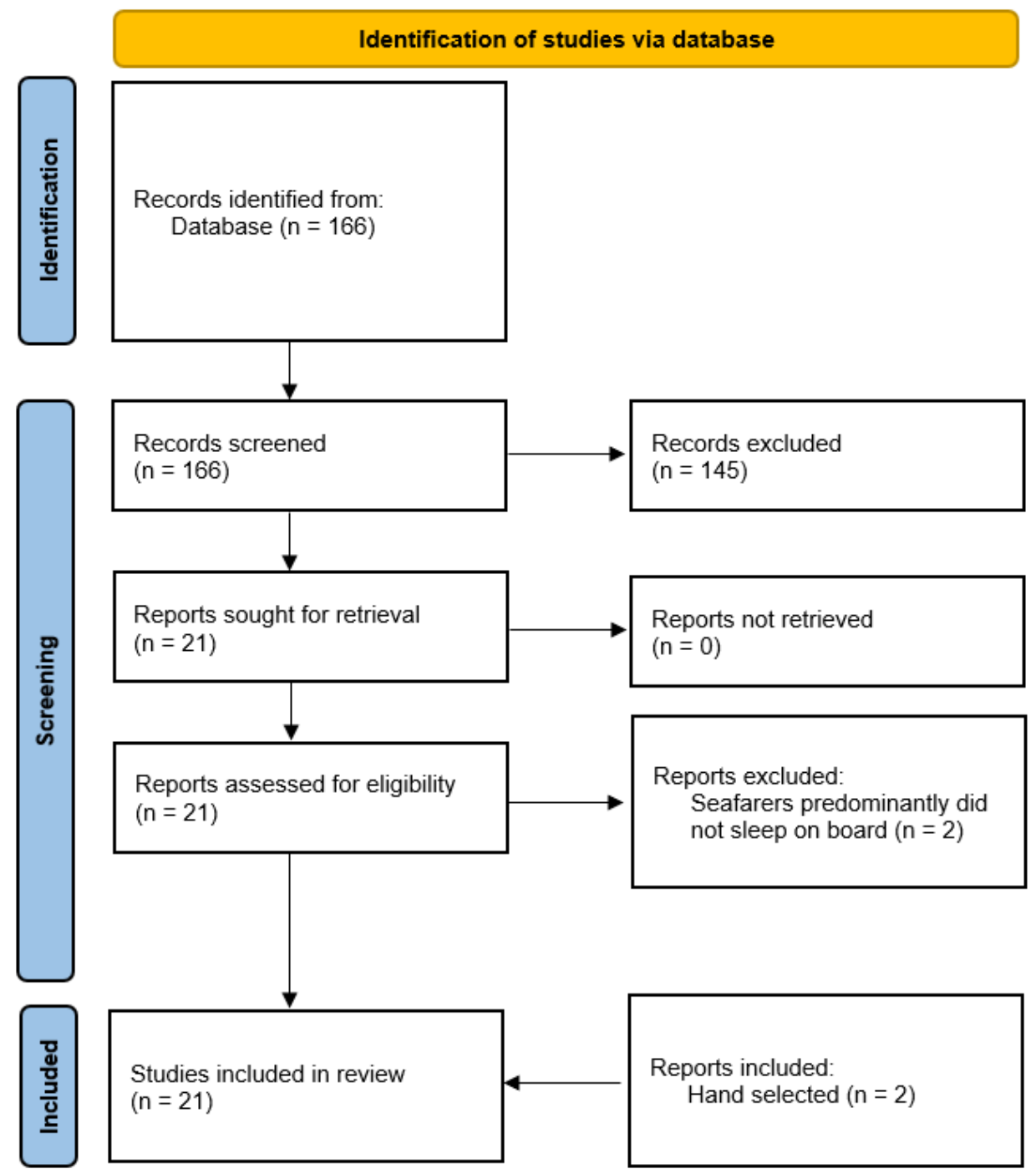

Figure 1. Search strategy on maritime studies of fatigue, sleepiness, and sleep behaviour following the PRISMA statement.

The following inclusion criteria were established: field studies in English or German; study population $\geq 10$; seafarers were primarily assessed for fatigue, sleepiness, or sleep behaviour while sleeping on board; and use of standardized measurement methods.

After screening the abstracts, 145 studies were excluded since they did not meet the inclusion criteria $(n=97)$ or were not thematically related to seafaring $(n=48)$.

After full-text review, two additional studies were excluded because the seafarers predominantly did not sleep on board [14,15]. In addition, two studies were hand-selected (one of these studies included tests in a ship simulator [16], and the other had a participant number of only eight sailors [17]). Although these papers were initially eliminated accord- 
ing to exclusion criteria, they were included due to the use of polysomnography (PSG) as a medical standard for sleep assessment in a maritime context.

Finally, a total of 21 studies on fatigue, sleepiness, and sleep behaviour on board were included in the review. From the identified studies, information on the aim of the study; the study population; the methods of measurement of fatigue, sleepiness, and sleep behaviour of seafarers on board; and limitations of these measurement methods were summarised. In addition, the evidence levels of these studies were evaluated by the Scottish Intercollegiate Guidelines Network criteria [18].

\section{Results}

The selected 21 studies were maritime field studies, apart from the manually selected study by van Leeuwen et al. [16], which used a bridge simulator. The studies were conducted in the period from 2002 to 2018, with only ten studies reporting a specific study year. Overall, the evidence level of these studies ranged from $2-$ to $2+$, with eight studies meeting the SIGN criterion of $2-$ and 13 studies corresponding to the criterion of $2+$.

Populations varied from eight to 1269 subjects (median 84 subjects). Analysis of the studies' methods of measuring fatigue, sleepiness, and sleep behaviour revealed that 13 studies used both subjective and objective measurement methods. Six studies used only subjective tests, and two studies used only objective methods (Table 1).

\subsection{Subjective Measurement Methods}

Twelve different questionnaires (overview in Table 2), each with a different focus, as well as activity and sleep diaries were used to subjectively assess fatigue, sleepiness, and sleep behaviour (Table 1).

Fatigue was assessed by the Fatigue Severity Scale (FSS; $n=1$ ) and the Swedish Occupational Fatigue Inventory (SOFI; $n=3$ ) as well as the Samn-Perelli Fatigue Scale (SPFS; $n=1$ ), which is also known as the Crew Status Survey (CSS). Fatigue was also assessed in the Profile of Mood States (POMS; $n=3$ ) in conjunction with six other mood states. Work-associated fatigue was evaluated using the Need for Recovery Scale (NFR; $n=1)$.

Sleepiness was assessed using the Epworth Sleepiness Scale (ESS; $n=6)$, the Karolinska Sleepiness Scale (KSS; $n=2$ ), and the Stanford Sleepiness Scale (SSS; $n=1$ ).

Sleep quality was assessed using the Pittsburgh Sleep Quality Index (PSQI; $n=4$ ). Insomnia was assessed using the Insomnia Severity Index (ISI; $n=2$ ) and the Bergen Insomnia Scale (BIS; $n=1$ ). Possible sleep disorders were excluded using the Karolinska Sleep Questionnaire (KSQ; $n=1$ ).

Exact differentiation of the meaning of activity and sleep diaries appeared to be difficult, as the terms were often used synonymously. A comprehensive explanation of which data were collected at which intervals was often not provided. 
Table 1. Characteristics and methods of the selected studies.

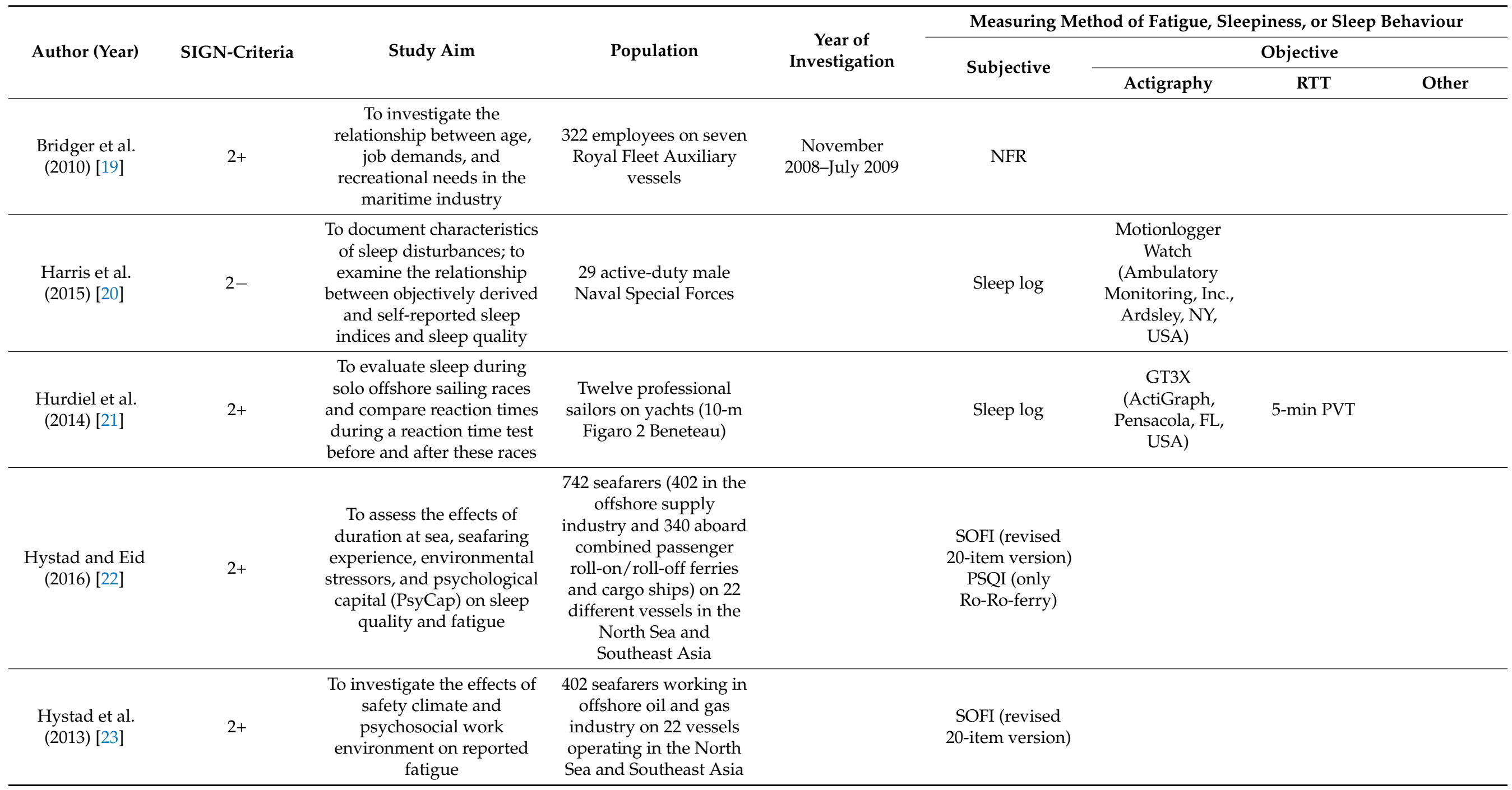


Table 1. Cont.

\begin{tabular}{|c|c|c|c|c|c|c|c|c|}
\hline \multirow{3}{*}{ Author (Year) } & \multirow{3}{*}{ SIGN-Criteria } & \multirow{3}{*}{ Study Aim } & \multirow{3}{*}{ Population } & \multirow{3}{*}{$\begin{array}{c}\text { Year of } \\
\text { Investigation }\end{array}$} & \multicolumn{4}{|c|}{ Measuring Method of Fatigue, Sleepiness, or Sleep Behaviour } \\
\hline & & & & & \multirow{2}{*}{ Subjective } & \multicolumn{3}{|c|}{ Objective } \\
\hline & & & & & & Actigraphy & RTT & Other \\
\hline $\begin{array}{l}\text { Jaipurkar et al. } \\
\text { (2019) [24] }\end{array}$ & $2-$ & $\begin{array}{l}\text { To assess and compare } \\
\text { sailors' work-rest rhythms } \\
\text { and alertness levels } \\
\text { during sailing and } \\
\text { non-sailing days; to } \\
\text { compare "sleep duration" } \\
\text { data as recorded in the } \\
\text { sleep diary with } \\
\text { actigraphy sleep data }\end{array}$ & $\begin{array}{l}32 \text { male participants } \\
\text { from a large Indian } \\
\text { naval vessel }\end{array}$ & & $\begin{array}{c}\text { Sleep } \log \text { Activity } \\
\log \end{array}$ & $\begin{array}{c}\text { Actiwatch } \\
\text { (Philips } \\
\text { Respironics, } \\
\text { Bend, OR, USA) }\end{array}$ & 5-min PVT & $\begin{array}{l}\text { Pulse und blood } \\
\text { pressure }\end{array}$ \\
\hline $\begin{array}{l}\text { Léger et al. } \\
\text { (2008) [17] }\end{array}$ & $2+$ & $\begin{array}{l}\text { To observe how sailors } \\
\text { manage their sleep and } \\
\text { alertness before and } \\
\text { during competition in a } \\
\text { long-distance regatta }\end{array}$ & $\begin{array}{l}\text { Eight sailors on yachts } \\
\text { during the race Tour de } \\
\text { France à la Voile } \\
\text { (Atlantic and } \\
\text { Mediterranean) }\end{array}$ & 2002 & Sleep log & & & $\begin{array}{c}\text { PSG: } \\
\text { Brainwalker } \\
\text { (Medatec software, } \\
\text { Braine-le-Château, } \\
\text { Belgium) } \\
\text { Night Cap: } \\
\text { REM view } \\
\text { (Respironics, Inc., } \\
\text { Bend, OR, USA) }\end{array}$ \\
\hline $\begin{array}{l}\text { Lützhöft et al. } \\
\text { (2010) [6] }\end{array}$ & $2+$ & $\begin{array}{l}\text { To investigate the degree } \\
\text { of fatigue on board and } \\
\text { compare } 6: 6 \text { with } 4: 8 \text { shift } \\
\text { schedules }\end{array}$ & $\begin{array}{l}30 \text { watchkeeping } \\
\text { nautical officers on } 13 \\
\text { Swedish cargo ships } \\
\text { (bulk carriers, car } \\
\text { carriers, and tankers; } \\
2300 \text { to } 11,000 \text { DWT) }\end{array}$ & 2005-2007 & KSS & $\begin{array}{c}\text { Actiwatch } \\
\text { (Cambridge } \\
\text { Neurotechnol- } \\
\text { ogy Ltd., } \\
\text { Cambridge, UK) }\end{array}$ & $\begin{array}{l}\text { 6-min } \\
\text { (RTT-type not } \\
\text { specified) }\end{array}$ & EOG \\
\hline $\begin{array}{c}\text { Matsangas and } \\
\text { Shattuck (2018) } \\
{[10]}\end{array}$ & $2-$ & $\begin{array}{c}\text { To assess similarities and } \\
\text { differences between } \\
\text { subjective reports of } \\
\text { fatigue/sleepiness; to } \\
\text { assess predictors of } \\
\text { sleepiness/fatigue; to } \\
\text { measure } \\
\text { sleepiness/fatigue }\end{array}$ & $\begin{array}{l}767 \text { crew members } \\
\text { (predominantly } \\
\text { watchkeepers) on a } \\
\text { U.S. Navy aircraft } \\
\text { carrier (NIMITZ, } \\
\text { CNV-68) }\end{array}$ & Spring 2014 & $\begin{array}{l}\text { ESS } \\
\text { FSS }\end{array}$ & & & \\
\hline
\end{tabular}


Table 1. Cont.

\begin{tabular}{|c|c|c|c|c|c|c|c|c|}
\hline \multirow{3}{*}{ Author (Year) } & \multirow{3}{*}{ SIGN-Criteria } & \multirow{3}{*}{ Study Aim } & \multirow{3}{*}{ Population } & \multirow{3}{*}{$\begin{array}{c}\text { Year of } \\
\text { Investigation }\end{array}$} & \multicolumn{4}{|c|}{ Measuring Method of Fatigue, Sleepiness, or Sleep Behaviour } \\
\hline & & & & & \multirow{2}{*}{ Subjective } & \multicolumn{3}{|c|}{ Objective } \\
\hline & & & & & & Actigraphy & RTT & Other \\
\hline $\begin{array}{c}\text { Matsangas and } \\
\text { Shattuck (2020) } \\
{[2]}\end{array}$ & $2+$ & $\begin{array}{l}\text { To assess the prevalence } \\
\text { of disruptive factors in } \\
\text { the sleep environment; to } \\
\text { assess whether these } \\
\text { disruptive factors affect } \\
\text { sleep and well-being }\end{array}$ & $\begin{array}{c}1269 \text { sailors (661 } \\
\text { watchkeepers and } 231 \\
\text { non-watchkeepers) on } \\
\text { five ships (one } \\
\text { Nimitz-class aircraft } \\
\text { carrier, one } \\
\text { Ticonderoga-class cruiser, } \\
\text { three Arleigh Burke-class } \\
\text { Flight IIA destroyers) }\end{array}$ & 2014-2017 & $\begin{array}{c}\text { ESS } \\
\text { PSQI } \\
\text { POMS } \\
\text { ISI } \\
\text { Activity log }\end{array}$ & $\begin{array}{l}\text { Motionlogger Watch } \\
\text { (Ambulatory } \\
\text { Monitoring, Inc., } \\
\text { Ardsley, NY, USA) } \\
\text { Spectrum Plus } \\
\text { (Philips Respironics, } \\
\text { Bend, OR, USA) }\end{array}$ & & \\
\hline $\begin{array}{c}\text { Matsangas and } \\
\text { Shattuck (2020) } \\
{[25]}\end{array}$ & $2+$ & $\begin{array}{l}\text { To assess sleep quality } \\
\text { and examine whether } \\
\text { Pittsburgh Sleep Quality } \\
\text { Index (PSQI) scores are } \\
\text { influenced by } \\
\text { occupational factors and } \\
\text { sleep attributes and } \\
\text { whether PSQI can predict } \\
\text { impaired PVT } \\
\text { performance }\end{array}$ & $\begin{array}{c}872 \text { USN sailors (666 } \\
\text { watchkeepers and } 206 \\
\text { non-watchkeepers) on } \\
\text { seven USN “surface } \\
\text { combatants” (one } \\
\text { Nimitz-class aircraft } \\
\text { carrier, one } \\
\text { Ticonderoga-class cruiser, } \\
\text { and five Arleigh } \\
\text { Burke-class destroyers) }\end{array}$ & $\begin{array}{c}\text { Six periods } \\
\text { (December 2012, } \\
\text { May 2013, June } \\
\text { and November } \\
\text { 2014, June 2017, } \\
\text { December } \\
\text { 2017-January } \\
\text { 2018) }\end{array}$ & $\begin{array}{c}\text { PSQI } \\
\text { Sleep log } \\
\text { Activity log }\end{array}$ & $\begin{array}{l}\text { Motionlogger Watch } \\
\text { (Ambulatory } \\
\text { Monitoring, Inc., } \\
\text { Ardsley, NY, USA) } \\
\text { Actiwatch Spectrum } \\
\text { (Philips Respironics, } \\
\text { Bend, OR, USA) }\end{array}$ & 3-min PVT & \\
\hline $\begin{array}{l}\text { Nordmo et al. } \\
\text { (2017) [26] }\end{array}$ & $2-$ & $\begin{array}{c}\text { To examine the } \\
\text { association between } \\
\text { hardiness and reported } \\
\text { insomnia symptoms in a } \\
\text { maritime military } \\
\text { environment }\end{array}$ & $\begin{array}{l}281 \text { sailors, officers, and } \\
\text { enlisted personnel on a } \\
\text { Royal Norwegian Navy } \\
\text { frigate during a 4-month } \\
\text { naval deployment to } \\
\text { combat piracy in the Gulf } \\
\text { of Aden }\end{array}$ & & BSI & & & \\
\hline $\begin{array}{c}\text { Oldenburg and } \\
\text { Jensen (2019) } \\
\text { [27] }\end{array}$ & $2+$ & $\begin{array}{l}\text { To assess the prevalence } \\
\text { of drowsiness in seafarers } \\
\text { during sea passage with a } \\
\text { distinction between day } \\
\text { workers and } \\
\text { watchkeepers }\end{array}$ & $\begin{array}{l}75 \text { day workers and } 123 \\
\text { watchkeepers during } 18 \\
\text { voyages on } 18 \text { different } \\
\text { container ships }\end{array}$ & & $\begin{array}{l}\text { ESS } \\
\text { SSS }\end{array}$ & $\begin{array}{l}\text { SenseWear armband } \\
\text { activity monitor } \\
\text { (BodyMedia, Inc., } \\
\text { Pittsburgh, PA, } \\
\text { USA) }\end{array}$ & & Pupillometry \\
\hline
\end{tabular}


Table 1. Cont.

\begin{tabular}{|c|c|c|c|c|c|c|c|c|}
\hline \multirow{3}{*}{ Author (Year) } & \multirow{3}{*}{ SIGN-Criteria } & \multirow{3}{*}{ Study Aim } & \multirow{3}{*}{ Population } & \multirow{3}{*}{$\begin{array}{c}\text { Year of } \\
\text { Investigation }\end{array}$} & \multicolumn{4}{|c|}{ Measuring Method of Fatigue, Sleepiness, or Sleep Behaviour } \\
\hline & & & & & \multirow{2}{*}{ Subjective } & \multicolumn{3}{|c|}{ Objective } \\
\hline & & & & & & Actigraphy & RTT & Other \\
\hline $\begin{array}{l}\text { Shattuck and } \\
\text { Matsangas } \\
(2016)[28]\end{array}$ & $2-$ & $\begin{array}{l}\text { To assess mood, sleep } \\
\text { patterns, daytime } \\
\text { sleepiness, and } \\
\text { psychomotor vigilance } \\
\text { performance during a } \\
\quad 5 / 10 \text { watch }\end{array}$ & $\begin{array}{l}77 \text { Reactor Division }(\mathrm{RX}) \\
\text { participants on the } \\
\text { aircraft carrier USS } \\
\text { Nimitz (CVN-68) }\end{array}$ & 10-27 June 2014 & $\begin{array}{c}\text { ESS } \\
\text { POMS } \\
\text { Activity log }\end{array}$ & $\begin{array}{l}\text { Motionlogger Watch } \\
\text { (Ambulatory } \\
\text { Monitoring, Inc., } \\
\text { Ardsley, NY, USA) } \\
\text { Actiwatch Spectrum } \\
\text { (Philips Respironics, } \\
\text { Bend, OR, USA) } \\
\end{array}$ & 3-min PVT & \\
\hline $\begin{array}{l}\text { Shattuck and } \\
\text { Matsangas } \\
(2017) \text { [29] }\end{array}$ & $2-$ & $\begin{array}{l}\text { To assess the impact of } \\
\text { sunlight, long working } \\
\text { hours, and caffeinated } \\
\text { beverages on average } \\
\text { daily sleep duration }\end{array}$ & $\begin{array}{c}91 \text { U.S. Navy crew } \\
\text { members ( } 65 \text { men) on } \\
\text { the aircraft carrier USS } \\
\text { Nimitz }\end{array}$ & $\begin{array}{c}\text { 3-14 November } \\
2014\end{array}$ & $\begin{array}{c}\text { ESS } \\
\text { Activity log }\end{array}$ & $\begin{array}{c}\text { Motionlogger Watch } \\
\text { (Ambulatory } \\
\text { Monitoring, Inc., } \\
\text { Ardsley, NY, USA) }\end{array}$ & & \\
\hline $\begin{array}{l}\text { Shattuck and } \\
\text { Matsangas } \\
(2020)[30]\end{array}$ & $2+$ & $\begin{array}{c}\text { To compare the } \\
\text { well-being and sleep of } \\
\text { dayworkers and shift } \\
\text { workers }\end{array}$ & $\begin{array}{c}804 \text { sailors }(78.4 \% \text { male }) \\
\text { on seven U.S. Navy } \\
\text { ships }\end{array}$ & & $\begin{array}{c}\text { ESS } \\
\text { PSQI } \\
\text { POMS } \\
\text { ISI } \\
\text { Activity log }\end{array}$ & $\begin{array}{l}\text { Motionlogger Watch } \\
\text { (Ambulatory } \\
\text { Monitoring, Ardsley, } \\
\text { NY, USA) } \\
\text { Spectrum Plus } \\
\text { (Philips Respironics, } \\
\text { Bend, OR, USA) }\end{array}$ & & \\
\hline $\begin{array}{l}\text { Sunde et al. } \\
\text { (2016) [31] }\end{array}$ & $2+$ & $\begin{array}{c}\text { To assess relationships } \\
\text { between noise exposure } \\
\text { during sleep and } \\
\text { actigraphy-derived sleep } \\
\text { parameter }\end{array}$ & $\begin{array}{l}72 \text { participants from } \\
\text { different occupational } \\
\text { groups on board } \\
\text { (engineers, navigators, } \\
\text { cooks, etc.) on } 21 \text { Royal } \\
\text { Norwegian Navy ships }\end{array}$ & $\begin{array}{c}\text { April 2012-June } \\
2013\end{array}$ & & $\begin{array}{c}\text { Actiwatch AW4 } \\
\text { (Cambridge } \\
\text { Neurotechnology Ltd., } \\
\text { Cambridge, UK) } \\
\text { Actiwatch 2 (Philips } \\
\text { Respironics, Bend, OR, } \\
\text { USA) }\end{array}$ & & \\
\hline $\begin{array}{l}\text { Thomas et al. } \\
\text { (2019) [32] }\end{array}$ & $2-$ & $\begin{array}{l}\text { To investigate the } \\
\text { consequences of fatigue } \\
\text { and workload associated } \\
\text { with increased } \\
\text { operational stress }\end{array}$ & $\begin{array}{c}12 \text { senior staff on board } \\
\text { a roll-on roll-off ferry in } \\
\text { Australia }\end{array}$ & & CSS/SPFS & $\begin{array}{l}\text { Unspecified device } \\
\text { (Philips Respironics, } \\
\text { Bend, OR, USA) }\end{array}$ & 5-min PVT & \\
\hline
\end{tabular}


Table 1. Cont.

\begin{tabular}{|c|c|c|c|c|c|c|c|c|}
\hline \multirow{3}{*}{ Author (Year) } & \multirow{3}{*}{ SIGN-Criteria } & \multirow{3}{*}{ Study Aim } & \multirow{3}{*}{ Population } & \multirow{3}{*}{$\begin{array}{c}\text { Year of } \\
\text { Investigation }\end{array}$} & \multicolumn{4}{|c|}{ Measuring Method of Fatigue, Sleepiness, or Sleep Behaviour } \\
\hline & & & & & \multirow{2}{*}{ Subjective } & \multicolumn{3}{|c|}{ Objective } \\
\hline & & & & & & Actigraphy & RTT & Other \\
\hline $\begin{array}{l}\text { Valdersnes et al. } \\
\text { (2017) [33] }\end{array}$ & $2+$ & $\begin{array}{l}\text { To investigate the } \\
\text { relationship between } \\
\text { worries about possible } \\
\text { accidents and sleepiness } \\
\text { in seafarers; to investigate } \\
\text { PsyCap as a protective } \\
\text { factor in this context }\end{array}$ & $\begin{array}{l}397 \text { seafarers from a } \\
\text { Norwegian company in } \\
\text { the offshore oil and gas } \\
\text { industry on } 22 \text { ships in } \\
\text { the North Sea and } \\
\text { Southeast Asia }\end{array}$ & 2012 & SOFI & & & \\
\hline $\begin{array}{l}\text { van Leeuwen } \\
\text { et al. (2013) [16] }\end{array}$ & $2-$ & $\begin{array}{c}\text { To investigate sleep, } \\
\text { sleepiness, and } \\
\text { neuro-behavioural } \\
\text { performance in a } \\
\text { simulated } 4: 8 \text { watch } \\
\text { system and the effects of } \\
\text { disrupting a single free } \\
\text { watch simulating a } \\
\text { condition of overtime } \\
\text { work }\end{array}$ & $\begin{array}{l}30 \text { bridge officers ( } 29 \text { men) } \\
\text { measured with a bridge } \\
\text { simulator at Chalmers } \\
\text { University of Technology, } \\
\text { Gothenburg, who slept on } \\
\text { the passenger ship } \\
\text { "Origo" }\end{array}$ & & $\begin{array}{l}\text { KSQ } \\
\text { KSS } \\
\text { KSD }\end{array}$ & & 5-min PVT & $\begin{array}{c}\text { PSG: } \\
\text { Vitaport } 3 \\
\text { recorders } \\
\text { (TEMEC, } \\
\text { Kerkrade, The } \\
\text { Netherlands) }\end{array}$ \\
\hline $\begin{array}{l}\text { Youn and Lee } \\
\text { (2020) [34] }\end{array}$ & $2+$ & $\begin{array}{l}\text { To compare the physical } \\
\text { activity intensity and } \\
\text { sleep patterns under three } \\
\text { conditions: (1) moored } \\
\text { versus sailing, (2) } \\
\text { on-navigation duty and } \\
\text { off-navigation duty, and } \\
\text { (3) day versus night } \\
\text { navigation duty }\end{array}$ & $\begin{array}{l}51 \text { senior naval students } \\
\text { (10 female and } 41 \text { male) of } \\
\text { the navigation } \\
\text { department on training } \\
\text { vessels of Mokpo } \\
\text { National Maritime } \\
\text { University in South Korea } \\
\text { on three sea voyages }\end{array}$ & & & $\begin{array}{c}\text { ActiGraph GT9X } \\
\text { Link (ActiGraph, } \\
\text { Pensacola, FL, USA) }\end{array}$ & & \\
\hline
\end{tabular}


Table 2. Overview of questionnaires used on board.

\begin{tabular}{llc}
\hline \multicolumn{1}{c}{ Questionnaires } & Number of Studies \\
\hline Fatigue & 3 \\
\hline$-\quad$ Swedish Occupational Fatigue Inventory (SOFI) & 3 \\
$-\quad$ Profile of Mood States (POMS) & 1 \\
$-\quad$ Fatigue Severity Scale (FSS) & 1 \\
$-\quad$ Need for Recovery Scale (NFR) & 1 \\
$-\quad$ Samn-Perelli Fatigue Scale (SPFS)/Crew Status Survey CSS & 9 \\
\hline Sleepiness & 6 \\
\hline$-\quad$ Epworth Sleepiness Scale (ESS) & 2 \\
$-\quad$ Karolinska Sleepiness Scale (KSS) & 1 \\
\hline & Stanford Sleepiness Scale (SSS) & 8 \\
\hline Sleep behaviour & 4 \\
\hline$-\quad$ Pittsburgh Sleep Quality Index (PSQI) & 2 \\
\hline & Insomnia Severity Index (ISI) & 1 \\
\hline & Bergen Insomnia Scale (BIS) & 1 \\
\hline
\end{tabular}

\subsection{Objective Measurement Methods}

A total of seven different objective measurement methods were recorded in the selected studies. Of these, actigraphy was by far the most commonly used to determine sleep duration and quality. A total of nine different devices from five different manufacturers were used in 13 studies although only the manufacturer (not device designation) was reported in the study by Thomas et al. [32]. In this study selection, a tendency towards devices from Philips Respironics (Actiwatch Spectrum = 2; Actiwatch Spectrum Plus = 2; Actiwatch $=1$; Actiwatch $2=1$; no model specified $=1$ ) and the Motionlogger Watch from Ambulatory Monitoring $(n=6)$ emerged. In addition, devices from ActiGraph (GT9X Link = 1; GT3X = 1), Cambridge Neurotechnology (Actiwatch = 1; Actiwatch AW4 = 1), and BodyMedia (SenseWear armband activity monitor $=1$ ) were used. A comparison of these actigraphy devices revealed that five of the ten actigraphs were currently still offered for sale by the respective manufacturers (as of December 2021) (see Appendix A, Table A1).

The second most used method was a reaction time test (RTT) to objectively measure drowsiness-related limitations $(n=7)$. Twelve studies used the reaction time test procedure of the psychomotor vigilance test (PVT).

Ambulatory polysomnography (PSG) was used in two studies. Léger et al. [17] used PSG on sailing yachts during a race to measure TST (total sleep time) and TSD (total sleep debt) on board. A night-cap (a head actigraph with EOG) was used beforehand to determine TST. In the study by van Leeuwen et al. [16], the PSG was used in a bridge simulator to record sleepiness during watch.

Furthermore, Lützhöft et al. [6] captured sleepiness using EOG measurements, and Oldenburg and Jensen [27] investigated the effects of sleepiness using pupillometry. Jaipurkar et al. [24] additionally used pulse and blood pressure measurements to compare the persons' physical changes on land and at sea.

A few studies determined parameters about the onboard sleep environment. First, noise dosimeters [31] and wet bulb thermometers [24] were used. Second, environmental conditions (e.g., temperature, noise, light, air quality, odours, ventilation, and ship motion) were subjectively surveyed [2].

\section{Discussion}

The review included 21 studies that examined fatigue, sleepiness, and sleep behaviour of seafarers in their shipboard work environment. It was found that many different subjective and objective measurement methods have already been used on board for this purpose. Although few acute measurement problems were reported in the selected studies, general limitations of these methods should also be considered. A summarising overview of the generally known strengths and weaknesses of each method is given in Table 3 . 
Table 3. Strengths and weaknesses of measuring methods for sleep, fatigue, and sleep behaviour in the maritime-specific study setting.

\begin{tabular}{|c|c|c|c|}
\hline Method & Strengths & Weaknesses & $\begin{array}{c}\text { Weaknesses in the Maritime-Specific } \\
\text { Setting }\end{array}$ \\
\hline Subjective in general & $\begin{array}{l}\text { Suitable for large collectives } \\
\text { Cost-effective } \\
\text { No investigator on board necessary } \\
\text { Suitable for long-term studies }\end{array}$ & Lack of motivation and compliance & \\
\hline Questionnaires & $\begin{array}{l}\text { Different questionnaires for special questions } \\
\text { (e.g., fatigue, sleepiness, sleep quality) }\end{array}$ & $\begin{array}{c}\text { Recall bias } \\
\text { Use of different cut-off values } \\
\text { Risk of social desirability with time contracts or } \\
\text { interviewer presence }\end{array}$ & $\begin{array}{c}\text { Designed for land context (ESS contains } \\
\text { question on road behaviour) }\end{array}$ \\
\hline Activity and sleep diaries & $\begin{array}{l}\text { Easy individual adaptation to study design } \\
\text { Supplementation of missing actigraphy data }\end{array}$ & $\begin{array}{l}\text { Often poor comparability due to inconsistent format } \\
\text { Sleep duration and quality often overestimated }\end{array}$ & \\
\hline Objective in general & $\begin{array}{l}\text { Independent of motivation, recall bias, social } \\
\text { desirability }\end{array}$ & $\begin{array}{l}\text { Study population limited by number of devices } \\
\text { Investigator on board necessary }\end{array}$ & \\
\hline $\begin{array}{c}\text { Reaction Time Test (RTT)/Psychomotor } \\
\text { Vigilance Test (PVT) }\end{array}$ & $\begin{array}{c}\text { Cost-effective } \\
\text { Gold standard for detecting sleepiness-related } \\
\text { vigilance reduction }\end{array}$ & $\begin{array}{l}\text { Only captures effect of sleepiness } \\
\text { (Ship) movement and noise can falsify measurements }\end{array}$ & \\
\hline Electrooculography (EOG) & & $\begin{array}{c}\text { Motion artifacts } \\
\text { Interindividual different blinking characteristics } \\
\text { Time-consuming evaluation }\end{array}$ & \\
\hline Actigraphy & $\begin{array}{c}\text { Cost-effective } \\
\text { Suitable for long-term studies } \\
\text { Hardly any first-night effect } \\
\text { Good agreement with PSG in TST, SOL, SE\% }\end{array}$ & $\begin{array}{l}\text { No display of sleep architecture } \\
\text { Overestimation of sleep periods } \\
\text { Underestimation of the wake stage }\end{array}$ & $\begin{array}{l}\text { Motion artifacts due to strong sea } \\
\text { state/high speed }\end{array}$ \\
\hline $\begin{array}{c}\text { Ambulatory } \\
\text { Polysomnography (PSG) }\end{array}$ & $\begin{array}{c}\text { Comparable with stationary PSG (gold standard } \\
\text { of sleep diagnostics) } \\
\text { Display of sleep architecture } \\
\text { Possibly hardly/less first night effect (in } \\
\text { contrast to stationary PSG) }\end{array}$ & $\begin{array}{c}\text { Cost intensive } \\
\text { Time-consuming measurement and evaluation }\end{array}$ & \\
\hline
\end{tabular}




\subsection{Subjective Measurement Methods and Limitations}

\subsubsection{Questionnaires}

Questionnaires were used as subjective testing methods in 15 of the 21 studies. Besides lack of motivation, compliance [6], and recall bias, the factor of social desirability plays a limiting role [16] - especially when respondents fear negative reactions from their superiors when indicating fatigue or exhaustion. This could be relevant, for example, in the context of temporary contracts, which are commonly used in the shipping industry [22].

Moreover, the presence of interviewers could have a negative impact on responses. In a maritime study by Bridger et al. [19], there was a significant increase in Need for Recovery (NFR) scores during the second questionnaire survey, which was conducted without an interviewer, unlike the initial survey. However, Bridger et al. [19] suggested that the increased scores could also be due to the fact that seafarers affected by fatigue were more likely to participate in the second survey as well.

Furthermore, there is the possibility that the multicultural seafarer sample has a crucial impact on the response behaviour. On the one hand, misunderstanding may occur due to difficulties in understanding because of language barriers or low educational level. On the other hand, intercultural differences may influence the individual interpretation of the questions [33].

In general, questionnaires offer a variety of ways to subjectively measure fatigue, sleepiness, or sleep problems. Existing reviews offer an overview to find the appropriate test for the respective research question [7,35]. Particular attention should be paid to the distinction between fatigue and sleepiness. This was clarified by Matsangas and Shattuck [10] comparing the correlation of the ESS and FSS questionnaires of U.S. Navy crew members. They found that subjects' subjective fatigue did not necessarily correlate with subjective sleepiness, so these should be considered as different constructs.

Moreover, it should be taken into account that questionnaires were generally originally designed for the land context and not for the use at sea. For example, the ESS questionnaire includes a question on road traffic, which cannot be answered by all seafarers from personal experience [36].

In addition, different questionnaire cut-off values might complicate a uniform evaluation. For example, Matsangas and Shattuck [10] reported different FSS cut-offs ranging from $>3$ to $\geq 5.4$ (Table 3).

\subsubsection{Diaries}

In 10 of the 21 studies, sleep or activity diaries were used. An advantage of this method is the flexible design, which can be individually adapted to the study design. Nevertheless, this fact makes it difficult to compare the studies with each other. According to Quante et al. [37], there is no standardized format for an activity diary. However, recommendations for sleep diaries exist in English-speaking [38] as well as in German-speaking countries [11].

Using diaries alone to determine sleep duration and quality is not recommended as their results are often subjectively overestimated [20,24]. However, in two of the selected studies, diaries are reported as a helpful adjunct to actigraphy to supplement missing actigraphy data $[25,30]$. Supplementing sleep measurements with diaries could be particularly useful for shipboard measurements if actigraphy data cannot be analysed, e.g., due to heavy ship-movements.

\subsection{Objective Measurement Methods, Differences and Limitations}

In the included 21 studies, objective measurement methods were applied in 15 cases. None of these studies mentioned that the use of an objective measurement method would have significantly disrupted the daily routines, and thus, the routine activities of the seafarers on board and only a few limitations were attributed to maritime causes. 


\subsubsection{Actigraphy}

Actigraphy was the most commonly used objective measurement method on board in the identified studies. It represents a validated method for assessing sleep and wake patterns in field studies over long periods of time [25]. As a limitation, it can be seen that measurements that require specialised, complex equipment are less suitable for simultaneous investigation of large study populations (Table 3). For example, Jaipurkar et al. [24] stated that not all 50 subjects on board could be equipped with actigraphs at the same time. In addition, objective measurements require the presence of investigators on board. This results in a more laborious and expensive implementation and may also cause a Hawthorn effect [39]. Furthermore, actigraphic measurements can be susceptible to ship movements. Sunde et al. [31] had to exclude $6 \%$ of the actigraphy recordings because a sea state $>3$ as well as very high speeds affected the reliability of the actigraph on board.

\subsubsection{Electrooculography (EOG)}

It should additionally be noted that even objective measurement methods are not entirely free of interindividual differences. Although an association between sleepiness and increased blink measurements in the EOG is assumed, Lützhöft et al. [6] indicated that blink characteristics vary for people individually. Therefore, EOG measurements should not be used exclusively to determine sleepiness.

Additionally, the measurement environment may negatively affect the results. The measurement problems of objective methods reported in the present study selection suggest that increased vessel motion may influence actigraphy and EOG results [6,31]. However, an underreporting of similar measurement inaccuracies in other studies can be presumed. It is assumed that actigraphy, EOG, and correspondingly PSG measurements can be well performed when extreme weather conditions do not occur.

\subsubsection{Pupillometry}

Conducting pupillometry measurements with completely darkening goggles, as in the study by Oldenburg and Jensen [27], is necessary because ambient light conditions have been shown to affect pupil parameters during pupillometry [40]. In addition, strong vessel motion or noise disturbances could impact pupillometric measurements, as we can report from our own experience that subjects can be distracted, and measurements can be biased as a result.

\subsubsection{Reaction Time Tests (RTT)}

Such distracting environmental conditions could also have a negative effect on the reliability of an RTT measurement, as this test requires the undivided attention of the subjects. In addition, it is recommended that the time of day and the awake time of the subjects should be taken into account when performing an RTT. Reaction time may be significantly slowed when testing does not coincide with natural biological sleep-wake cycles, as is often the case with shift workers (e.g., on board) [41].

\subsubsection{Polysomnography (PSG)}

In contrast to actigraphy, the use of ambulatory PSG aboard ships has not been adequately studied to date, according to our research. However, studies from comparable workplace-specific contexts showed that reliable polysomnographic measurements in unusual environments are indeed possible.

Measurements were conducted either in a bridge simulator [16] or during a yacht race [17]. Jay et al. [42] studied the sleep of train drivers who worked an 8:8 shift system and slept in so-called "relay vans" on board. The authors emphasized the benefits of PSG over previous actigraphy studies, as it allowed them to evaluate new aspects of sleep quality. Because of the shift work associated with movement, vibration, and noise of the sleep environment, this study design shows parallels to maritime field studies. Polysomnographic measurements in an environment characterized by noise and turbulence 
have likewise been used on airplanes [43]. In the study by Mitler et al. [44], truck drivers were monitored while driving using EOG and camera recordings. In addition, their sleep was recorded using PSG in accommodations along their route. Mairesse et al. [45] performed wireless PSG measurements with two-channel EEG devices at the Antarctic research station "Concordia", which yielded good results despite limited PSG set-up.

In these four studies, no significant interference of ambulatory PSG by the unusual measurement environments was mentioned. This fact suggests that reliable polysomnographic measurements in unusual environments-which may well resemble conditions on board ships-can be possible without major interference.

\subsection{Comparison of Actigraphy and PSG}

In contrast to PSG, the use of actigraphs is considered cost effective and non-disruptive (Table 3). Actigraphic measurements are less disturbing to sleep architecture than PSG and are unlikely to be limited by a first night effect [46]. In addition, actigraphy is an established method in field studies investigating circadian rhythms and is also indicated in the assessment of individuals with shift work disorders [47].

According to Quante et al. [37], there is no universal minimum duration of an actigraphy measurement to obtain the most reliable results. The Standards of Practice Committee of the American Academy of Sleep Medicine recommends a minimum of three consecutive 24-h actigraphy measurements to obtain reliable sleep-wake estimates [48]. Nevertheless, in the International Classification of Sleep Disorders (ICSD-3), a minimum duration of actigraphy measurements over seven days in combination with diaries is usually recommended. In case of circadian rhythm disturbances-which are of particular interest in the maritime context-actigraphy should be conducted for at least 14 days [49].

However, actigraphy is not suitable for studying sleep architecture because it is based only on accelerometery [50]. Thus, sleep can easily be overestimated and wakefulness underestimated [51]. This low specificity for detecting waking phases during sleep is reflected in lower validity in individuals with poor sleep quality. In addition, awake phases also increase with age so that the accuracy of actigraphy decreases age dependently [52]. Despite these limitations, studies with young and healthy subjects showed $91-93 \%$ agreement between actigraphy and PSG in common measurement parameters, such as total sleep time or sleep efficiency [11]. However, it should be kept in mind that the correlation of actigraphy and PSG parameters is significantly dependent on the placement of the actigraph [46]. Thus, placement of the actigraph at the wrists showed better agreement than measurements via hip sensors.

Overall, stationary PSG represents the gold standard of sleep diagnostics. In contrast to actigraphy, it is suitable for the diagnosis of sleep-related breathing disorders, such as obstructive sleep apnoea syndrome [53]. It has been proven that ambulatory PSG achieved similar results to stationary PSG in comparative studies [54,55]. Whether a first-night effect also occurs in ambulatory PSG has not been conclusively established [55-58].

\subsection{Comparison of Subjective and Objective Measurement Methods}

In the literature, a rather low correlation of subjective and objective sleep or sleepiness measurement methods is assumed. While objective methods capture physiological aspects of sleepiness, subjective data depend on the introspection ability of the subjects [11]. The study by Oldenburg and Jensen [27] also showed only a weak correlation of subjective Stanford Sleepiness Scale (SSS) values with pupillometry data. It was striking that especially the younger, more inexperienced seafarers self-assessed their sleepiness more severely than this could be objectified by pupillometry. Here, the authors indicated that pupillometry had not yet been an established and universally accepted screening method for measuring sleepiness. In other studies, however, pupillometry was meanwhile described as established and widely used $[59,60]$.

Youn and Lee [34] based their choice of method on the fact that objective measurement methods are superior to subjective measurement methods in terms of feasibility, validity, 
and reliability. Matsangas and Shattuck [25] found an association of Pittsburgh Sleep Quality Index (PSQI) scores > 9 with elevated PVT scores. They suggested screening risk groups using questionnaires and examining only subjects at increased risk more closely by using objective methods.

In general, we found that subjective and objective methods were often used complementarily. Therefore, it seems reasonable to choose a combined study design and, for example, complement actigraphy measurements with sleep diaries [61]. Further studies should be conducted to directly compare subjective and objective measurement methods for fatigue, sleepiness, or sleep behaviour in a maritime context.

\subsection{Influences of Stress on Fatigue, Sleepiness, and Sleep Behaviour}

Two of the studies focused on the relationship of stress to fatigue, sleepiness or sleep behaviour.

Hystad and Eid [22] were able to show a correlation between disruptive environmental influences with reduced sleep quality and fatigue. Furthermore, low psychological capital (PsyCap) also predicted fatigue and poor sleep quality. PsyCap is a construct based on ideas from positive psychology defined as an individual's level of high self-efficacy, optimism, hope, and resiliency. The findings on PsyCap are particularly interesting as PsyCap is seen as a changeable and developmentally characteristic. Interventions to develop PsyCap could therefore be a relatively simple and cost-effective way for maritime organisations to address fatigue and poor sleep quality in their employees.

Moreover, Thomas et al. [32] investigated the effects of increased workload of rollon roll-off ferry workers during the summer "double sailing period". Since participants had the opportunity to adjust their sleep duration to the increased workload, subjective assessment of fatigue as well as neurological performance were not negatively affected. Accordingly, this study outlined the adaption of sleep duration to changing working hours as an example of a functioning fatigue-risk management system, which can help maintain sleep and performance during periods of increased work intensity.

\subsection{Further Factors That Should Be Considered in Measurements of Fatigue, Sleep, and Sleep Behaviour on Board}

In addition to standardised questionnaires, individual parameters of seafarers should be taken into account. A survey of medication intake (especially of stimulating or sedative substances) as well as the seafarers' general lifestyle (caffeinated beverages, alcohol consumption, physical fitness) seems advisable. For example, in their review on the use of addictive substances among seafarers, Pougnet et al. [62] found an increased prevalence of tobacco and alcohol use compared to the general population.

Additionally, it is useful to consider the individual circadian rhythm of seafarers. To determine the chronotype and thus the daily peak of attention, the Morningness-Eveningness Questionnaire (MEQ) is useful [63]. This questionnaire was applied in two of the selected studies [27,29].

Other important factors for sleep assessment relate to environmental conditions. Matsangas and Shattuck [2] reported that $91.6 \%$ of seafarers had their sleep disturbed by at least one environmental factor (noise, temperature, light, ship motion, odours, poor bedding). Indeed, another study demonstrated some subjective habituation to ship noise during sleep. However, actigraphic measurements did not confirm this subjective habituation effect [64]. During the study by Sunde et al. [31], noise was also associated with increased movements of seafarers during sleep and lower sleep efficiency. Therefore, especially in the maritime setting, it seems reasonable to incorporate the unusual sleep environment into the study design by, for example, measuring vibration, temperature, or noise to gain a better understanding if these factors may have disrupted sleep or sleep measurements.

In addition, measurements of fatigue, sleepiness, and sleep patterns on board should consider the respective variability for different shift systems, occupational groups, voyage episodes, and ship types. The guideline "Health aspects and design of night and shift work" 
("Gesundheitliche Aspekte und Gestaltung von Nacht- und Schichtarbeit") of the German Society for Occupational and Environmental Medicine [65] states that irregular shift times in particular are often associated with sleep deficits and fractional sleep periods. This was confirmed in the study by Arendt et al. [66], which investigated the sleep and circadian rhythms of seafarers. Among other things, they compared the effects of a constant 4:8 system with a weekly rotating schedule. It was found that weekly changes in waking times resulted in poorer sleep efficiency as well as fragmented sleep. Furthermore, divergent results were evident during various voyage episodes: port stay, river, or sea passage. Since working hours were usually longer during port stays, the crew had more free time and sleeping opportunity during sea passages. While seafarers slept an average of only $6.9 \mathrm{~h}$ in port, they were able to record $7.6 \mathrm{~h}$ of sleep during a river passage and $8.9 \mathrm{~h}$ at sea [67].

\section{Limitations}

As a limitation, it must be mentioned that the literature search was limited exclusively to German- and English-language publications. Furthermore, the comparison of the benefits of the individual measurement methods is impeded by the fact that some studies differed considerably in their study design as well as in the use of the various measurement methods (e.g., number, duration of measurement). A partly imprecise distinction between sleepiness and fatigue made the research more difficult. A comparison of objective and subjective methods took place only sporadically. In addition, very few studies stated that they had questioned interfering variables (e.g., ship movements, vibrations) during the study or that they had objectively recorded them or even adjusted them as influencing variables. For this reason, our results are partly based on assumptions due to missing information from the authors.

\section{Conclusions}

The possibilities of measuring fatigue, sleepiness, as well as sleep behaviour on board are various. Since the distinction of fatigue and sleepiness is not uniform in the literature, the choice of the best suitable measurement method is additionally complicated for the investigator. In general, our research showed that a combination of subjective and objective measurement methods can be beneficial. A wide range of questionnaires exists to investigate specific issues regarding fatigue, sleepiness, or sleep behaviour. Fatigue can only be determined subjectively. In this context, the most frequently used questionnaires were the Swedish Occupational Fatigue Inventory (SOFI) and the Profile of Mood States (POMS). Subjective sleepiness was most commonly assessed with the Epworth Sleepiness Scale (ESS). For the effect of sleepiness, reaction time measurements (RTT, PVT) as well as pupillometry can be used. To determine sleep behaviour over longer periods, the use of actigraphs in combination with diaries for a minimum period of three to seven days is recommended. To facilitate the consistent use of diaries, digital logs with reminder function, e.g., in the form of apps, could be used in the future. If an accurate determination of sleep parameters, a representation of sleep architecture or a diagnosis of sleep disorders, such as obstructive sleep apnoea syndrome, is requested, the use of an ambulatory PSG, which achieves comparable results to stationary PSG, is recommended.

In general, fewer measurement-related limitations on board were reported than expected. No disruptions of daily board routines were reported, and only single measurement disturbances due to ship movements were mentioned. The frequent use of actigraphy and PVT on board therefore implies good feasibility and reliable measurements with these methods. The use of ambulatory PSG in maritime-like contexts hints that this method would as well be feasible on board. However, a higher rate of unreported cases, especially with objective measurement problems, must be assumed. Thus, it cannot be extrapolated with certainty what impact the maritime environment actually has on the reliability of the measurement methods. Further studies on board are required for this. Nonetheless, this review provides a useful overview and orientation for future maritime studies. As the working and living conditions on board are unique and cannot be compared to those on 
land, occupation-specific studies in these demanding workplaces on board are essential and of high value. This study highlights the need to adjust the selection of measurement methods for fatigue, sleepiness, and sleep behaviour of seafarers to the specific conditions on board.

Author Contributions: F.K. wrote the manuscript with support from M.O. and D.D., F.K., M.O. and D.D. designed and directed the project and contributed to the final version of the manuscript. M.E., D.M.-K., L.B., F.A.N., B.C.Z. and V.H. proofread the manuscript and gave input to the final draft. All authors have read and agreed to the published version of the manuscript.

Funding: This study was funded by the European Regional Development Fund (ERDF) and the Free and Hanseatic City of Hamburg/Ministry of Labour, Health, Social, Family Affairs, and Integration.

Institutional Review Board Statement: Not applicable.

Informed Consent Statement: Not applicable.

Data Availability Statement: Not applicable.

Acknowledgments: The authors would like to thank our project partners Hanseaticsoft, Peter Döhle Schiffahrts KG, and Reederei Roth for their support.

Conflicts of Interest: The authors declare no conflict of interest. The funders had no role in the design of the study, in the collection, analyses, or interpretation of data, in the writing of the manuscript or in the decision to publish the results.

\section{Abbreviations}

BIS Bergen Insomnia Scale

CSS Crew Status Survey

EEG Electroencephalography

EOG Electrooculography

ESS Epworth Sleepiness Scale

FNE First Night Effect

FSS Fatigue Severity Scale

IMO International Maritime Organization

ISI Insomnia Severity Index

KSQ Karolinska Sleep Questionnaire

KSS Karolinska Sleepiness Scale

MEQ Morningness-Eveningness Questionnaire

NFR Need for Recovery Scale

OSA Obstructive Sleep Apnoea

POMS Profile of Mood States

PSG Polysomnography

PSQI Pittsburgh Sleep Quality Index

PsyCap Psychological Capital

PUI Pupil Unrest Index

PVT Psychomotor Vigilance Test

RTT Reaction Time Test

$\mathrm{SE} \% \quad$ Sleep Efficiency

SOFI Swedish Occupational Fatigue Inventory

SOL Sleep Onset Latency

SPFS Samn-Perelli Fatigue Scale

SSS Stanford Sleepiness Scale

TSD Total Sleep Debt

TST Total Sleep Time 


\section{Appendix A}

Table A1. Comparison of the available actigraphy devices used in the studies (as of December 2021).

\begin{tabular}{|c|c|c|c|c|c|}
\hline & $\begin{array}{l}\text { Actiwatch } 2 \\
\text { (Philips } \\
\text { Respironics) }\end{array}$ & $\begin{array}{c}\text { Actiwatch } \\
\text { Spectrum (Philips } \\
\text { Respironics) }\end{array}$ & $\begin{array}{c}\text { Actiwatch } \\
\text { Spectrum Plus } \\
\text { (Philips } \\
\text { Respironics) }\end{array}$ & $\begin{array}{c}\text { Motionlogger } \\
\text { Watch } \\
\text { (Ambulatory } \\
\text { Monitoring, Inc.) }\end{array}$ & $\begin{array}{l}\text { ActiGraph GT9X } \\
\text { Link (ActiGraph) }\end{array}$ \\
\hline Size $(\mathrm{cm})$ & $4.3 \times 2.3 \times 1.0$ & $4.8 \times 3.7 \times 1.4$ & $4.8 \times 3.7 \times 1.5$ & $4.4 \times 1.8 \times 1.5$ & $3.5 \times 3.5 \times 1.0$ \\
\hline Weight (g) & 16 & 30 & 31 & 65.2 & 14 \\
\hline Battery Life & 30 days & 8 months & 60 days & over 30 days & 14 days \\
\hline Water Resistance & $\begin{array}{l}1 \mathrm{~m} \text { for } 30 \mathrm{~min} \text { per } \\
\text { IPX7IEC } 60529\end{array}$ & $\begin{array}{l}1 \mathrm{~m} \text { for } 30 \mathrm{~min} \text { per } \\
\text { IPX7IEC } 60529\end{array}$ & $\begin{array}{c}1 \mathrm{~m} \text { for } 30 \mathrm{~min} \text { per } \\
\text { IPX7IEC } 60529\end{array}$ & $50 \mathrm{M}$ & $\mathrm{IP} 271 \mathrm{~m}, 30 \mathrm{~min}$ \\
\hline Wrist Detection & & $x$ & $x$ & $x$ & $x$ \\
\hline Light Sensor & $x$ & $x$ & $x$ & $x$ & \\
\hline Event Marker & $x$ & $x$ & $x$ & $x$ & \\
\hline Mean Temperature & & & & $x$ & \\
\hline $\begin{array}{c}\text { PVT Reaction Time } \\
\text { Rest }\end{array}$ & & & & $x$ & \\
\hline $\begin{array}{c}\text { Sensitivity } \\
\text { compared to PSG a }\end{array}$ & $90.8 \%{ }^{1}$ & $95.0 \%^{2}$ & - & $96.6 \%^{3}$ & - \\
\hline $\begin{array}{c}\text { Specificity } \\
\text { compared to PSG }\end{array}$ & $65.6 \%{ }^{1}$ & $34.0 \%^{2}$ & - & $65.9 \%^{3}$ & - \\
\hline
\end{tabular}

${ }^{1}$ Pigeon et al. [68], ${ }^{2}$ Quante et al. [69], ${ }^{3}$ Rupp and Balkin [70]; ${ }^{\text {P Percentage of PSG sleep episodes also identified }}$ as sleep by actigraphs; ${ }^{b}$ Percentage of non-sleep episodes correctly identified by actigraphs.

\section{References}

1. Oldenburg, M.; Baur, X.; Schlaich, C. Occupational risks and challenges of seafaring. J. Occup. Health 2010, 52, 249-256. [CrossRef]

2. Matsangas, P.; Shattuck, N.L. Habitability in Berthing Compartments and Well-Being of Sailors Working on U.S. Navy Surface Ships. Hum. Factors 2020, 63, 462-473. [CrossRef]

3. IMO. Guidelines on Fatigue. Available online: https://www.imo.org/en/OurWork/HumanElement/Pages/Fatigue.aspx (accessed on 23 April 2021).

4. Phillips, R. Sleep, watchkeeping and accidents: A content analysis of incident at sea reports. Transp. Res. Part F Traffic Psychol. Behav. 2000, 3, 229-240. [CrossRef]

5. Jepsen, J.R.; Zhao, Z.; van Leeuwen, W.M. Seafarer fatigue: A review of risk factors, consequences for seafarers' health and safety and options for mitigation. Int. Marit. Health 2015, 66, 106-117. [CrossRef] [PubMed]

6. Lützhöft, M.; Dahlgren, A.; Kircher, A.; Thorslund, B.; Gillberg, M. Fatigue at sea in Swedish shipping-a field study. Am. J. Ind. Med. 2010, 53, 733-740. [CrossRef]

7. Shahid, A.; Shen, J.; Shapiro, C.M. Measurements of sleepiness and fatigue. J. Psychosom. Res. 2010, 69, 81-89. [CrossRef] [PubMed]

8. Johns, M. Rethinking the assessment of sleepiness. Sleep Med. Rev. 1998, 2, 3-15. [CrossRef]

9. Phillips, R.O. What is Fatigue and How Does It Affect the Safety Performance of Human Transport Operators?-Fatigue in Transport Report I; 1351/2014; Institute of Transport Economics (TØI): Oslo, Norway, 2014.

10. Matsangas, P.; Shattuck, N.L. Discriminating Between Fatigue and Sleepiness in the Naval Operational Environment. Behav. Sleep Med. 2018, 16, 427-436. [CrossRef] [PubMed]

11. Weeß, H.-G. Diagnostische Methoden. In Praxis der Schlafmedizin: Diagnostik, Differenzialdiagnostik und Therapie bei Erwachsenen und Kindern, 3rd ed.; Stuck, B.A., Maurer, J.T., Schlarb, A.A., Schredl, M., Weeß, H.G., Eds.; Springer: Berlin, Germany, 2017; Volume 3, pp. 23-85.

12. Allen, P.; Wadsworth, E.; Smith, A. Seafarers' fatigue: A review of the recent literature. Int. Marit. Health 2008, 59, 81-92. [PubMed]

13. Page, M.J.; McKenzie, J.E.; Bossuyt, P.M.; Boutron, I.; Hoffmann, T.C.; Mulrow, C.D.; Shamseer, L.; Tetzlaff, J.M.; Akl, E.A.; Brennan, S.E.; et al. The PRISMA 2020 statement: An updated guideline for reporting systematic reviews. BMJ 2021, 372, n71. [CrossRef]

14. Dohrmann, S.B.; Herttua, K.; Leppin, A. Fatigue in ferry shipping employees: The role of work-family conflict and supervisor support. BMC Public Health 2019, 19, 1693. [CrossRef]

15. Dohrmann, S.B.; Herttua, K.; Leppin, A. Is physical and psychological work stress associated with fatigue in Danish ferry ship employees? Int. Marit. Health 2020, 71, 46-55. [CrossRef] [PubMed] 
16. Van Leeuwen, W.M.; Kircher, A.; Dahlgren, A.; Lützhöft, M.; Barnett, M.; Kecklund, G.; Åkerstedt, T. Sleep, sleepiness, and neurobehavioral performance while on watch in a simulated 4 hours on/8 hours off maritime watch system. Chronobiol. Int. 2013, 30, 1108-1115. [CrossRef] [PubMed]

17. Léger, D.; Elbaz, M.; Raffray, T.; Metlaine, A.; Bayon, V.; Duforez, F. Sleep management and the performance of eight sailors in the Tour de France à la voile yacht race. J. Sports Sci. 2008, 26, 21-28. [CrossRef]

18. SIGN. SIGN 50: A Guideline Developer's Handbook, Annex B: Key to Evidence Statements and Grades of Recommendations. Available online: https:/ / www.sign.ac.uk/assets/sign50_2011.pdf (accessed on 23 April 2021).

19. Bridger, R.S.; Brasher, K.; Dew, A. Work demands and need for recovery from work in ageing seafarers. Ergonomics 2010, 53, 1006-1015. [CrossRef] [PubMed]

20. Harris, E.; Taylor, M.K.; Drummond, S.P.; Larson, G.E.; Potterat, E.G. Assessment of Sleep Disruption and Sleep Quality in Naval Special Warfare Operators. Mil. Med. 2015, 180, 803-808. [CrossRef]

21. Hurdiel, R.; Van Dongen, H.P.; Aron, C.; McCauley, P.; Jacolot, L.; Theunynck, D. Sleep restriction and degraded reaction-time performance in Figaro solo sailing races. J. Sports Sci. 2014, 32, 172-174. [CrossRef]

22. Hystad, S.W.; Eid, J. Sleep and Fatigue Among Seafarers: The Role of Environmental Stressors, Duration at Sea and Psychological Capital. Saf. Health Work 2016, 7, 363-371. [CrossRef]

23. Hystad, S.W.; Saus, E.R.; Sætrevik, B.; Eid, J. Fatigue in seafarers working in the offshore oil and gas re-supply industry: Effects of safety climate, psychosocial work environment and shift arrangement. Int. Marit. Health 2013, 64, 72-79.

24. Jaipurkar, R.; Mahapatra, S.S.; Bobdey, S.; Banerji, C. Work-rest pattern, alertness and performance assessment among naval personnel deployed at sea: A cross sectional study. Med. J. Armed Forces India 2019, 75, 158-163. [CrossRef]

25. Matsangas, P.; Shattuck, N.L. Sleep Quality, Occupational Factors, and Psychomotor Vigilance Performance in U.S. Navy Sailors. Sleep 2020, 43, zsaa118. [CrossRef] [PubMed]

26. Nordmo, M.; Hystad, S.W.; Sanden, S.; Johnsen, B.H. The effect of hardiness on symptoms of insomnia during a naval mission. Int. Marit. Health 2017, 68, 147-152. [CrossRef] [PubMed]

27. Oldenburg, M.; Jensen, H.J. Sleepiness of day workers and watchkeepers on board at high seas: A cross-sectional study. BMJ Open 2019, 9, e028449. [CrossRef] [PubMed]

28. Shattuck, N.L.; Matsangas, P. Operational assessment of the 5-h on/10-h off watchstanding schedule on a US Navy ship: Sleep patterns, mood and psychomotor vigilance performance of crewmembers in the nuclear reactor department. Ergonomics 2016, 59, 657-664. [CrossRef]

29. Shattuck, N.L.; Matsangas, P. Sunlight Exposure, Work Hours, Caffeine Consumption, and Sleep Duration in the Naval Environment. Aerosp. Med. Hum. Perform. 2017, 88, 579-585. [CrossRef]

30. Shattuck, N.L.; Matsangas, P. Does the quality of life differ for shift workers compared to day workers? Chronobiol. Int. 2020, 37, 1299-1303. [CrossRef]

31. Sunde, E.; Bratveit, M.; Pallesen, S.; Moen, B.E. Noise and sleep on board vessels in the Royal Norwegian Navy. Noise Health 2016, 18, 85-92. [CrossRef]

32. Thomas, M.J.W.; Paterson, J.L.; Jay, S.M.; Matthews, R.W.; Ferguson, S.A. More than hours of work: Fatigue management during high-intensity maritime operations. Chronobiol. Int. 2019, 36, 143-149. [CrossRef]

33. Valdersnes, K.B.; Eid, J.; Hystad, S.W.; Nielsen, M.B. Does psychological capital moderate the relationship between worries about accidents and sleepiness? Int. Marit. Health 2017, 68, 245-251. [CrossRef]

34. Youn, I.H.; Lee, J.M. Seafarers' Physical Activity and Sleep Patterns: Results from Asia-Pacific Sea Routes. Int. J. Environ. Res. Public Health 2020, 17, 7266. [CrossRef]

35. Gawron, V.J. Overview of Self-Reported Measures of Fatigue. Int. J. Aviat. Psychol. 2016, 26, 120-131. [CrossRef]

36. Johns, M.W. A new method for measuring daytime sleepiness: The Epworth sleepiness scale. Sleep 1991, 14, 540-545. [CrossRef] [PubMed]

37. Quante, M.; Kaplan, E.R.; Rueschman, M.; Cailler, M.; Buxton, O.M.; Redline, S. Practical considerations in using accelerometers to assess physical activity, sedentary behavior, and sleep. Sleep Health 2015, 1, 275-284. [CrossRef] [PubMed]

38. Carney, C.E.; Buysse, D.J.; Ancoli-Israel, S.; Edinger, J.D.; Krystal, A.D.; Lichstein, K.L.; Morin, C.M. The Consensus Sleep Diary: Standardizing Prospective Sleep Self-Monitoring. Sleep 2012, 35, 287-302. [CrossRef] [PubMed]

39. McCambridge, J.; Witton, J.; Elbourne, D.R. Systematic review of the Hawthorne effect: New concepts are needed to study research participation effects. J. Clin. Epidemiol. 2014, 67, 267-277. [CrossRef] [PubMed]

40. Ong, C.; Hutch, M.; Smirnakis, S. The Effect of Ambient Light Conditions on Quantitative Pupillometry. Neurocrit. Care 2019, 30, 316-321. [CrossRef]

41. Ferris, M.; Bowles, K.A.; Bray, M.; Bosley, E.; Rajaratnam, S.M.W.; Wolkow, A.P. The impact of shift work schedules on PVT performance in naturalistic settings: A systematic review. Int. Arch. Occup. Environ. Health 2021, 94, 1475-1494. [CrossRef]

42. Jay, S.M.; Dawson, D.; Lamond, N. Train drivers' sleep quality and quantity during extended relay operations. Chronobiol. Int. 2006, 23, 1241-1252. [CrossRef]

43. Signal, T.L.; Gander, P.H.; van den Berg, M.J.; Graeber, R.C. In-flight sleep of flight crew during a 7-hour rest break: Implications for research and flight safety. Sleep 2013, 36, 109-115. [CrossRef]

44. Mitler, M.M.; Miller, J.C.; Lipsitz, J.J.; Walsh, J.K.; Wylie, C.D. The sleep of long-haul truck drivers. N. Engl. J. Med. 1997, 337, 755-761. [CrossRef] 
45. Mairesse, O.; MacDonald-Nethercott, E.; Neu, D.; Tellez, H.F.; Dessy, E.; Neyt, X.; Meeusen, R.; Pattyn, N. Preparing for Mars: Human sleep and performance during a 13 month stay in Antarctica. Sleep 2019, 42, zsy206. [CrossRef] [PubMed]

46. Zinkhan, M.; Berger, K.; Hense, S.; Nagel, M.; Obst, A.; Koch, B.; Penzel, T.; Fietze, I.; Ahrens, W.; Young, P.; et al. Agreement of different methods for assessing sleep characteristics: A comparison of two actigraphs, wrist and hip placement, and self-report with polysomnography. Sleep Med. 2014, 15, 1107-1114. [CrossRef] [PubMed]

47. Morgenthaler, T.; Alessi, C.; Friedman, L.; Owens, J.; Kapur, V.; Boehlecke, B.; Brown, T.; Chesson, A., Jr.; Coleman, J.; Lee-Chiong, T.; et al. Practice parameters for the use of actigraphy in the assessment of sleep and sleep disorders: An update for 2007. Sleep 2007, 30, 519-529. [CrossRef] [PubMed]

48. Smith, M.T.; McCrae, C.S.; Cheung, J.; Martin, J.L.; Harrod, C.G.; Heald, J.L.; Carden, K.A. Use of Actigraphy for the Evaluation of Sleep Disorders and Circadian Rhythm Sleep-Wake Disorders: An American Academy of Sleep Medicine Clinical Practice Guideline. J. Clin. Sleep Med. 2018, 14, 1231-1237. [CrossRef]

49. AASM. International Classification of Sleep Disorders, 3rd ed.; American Academy of Sleep Medicine: Darien, IL, USA, 2014.

50. Conradt, R.; Brandenburg, U.; Ploch, T.; Peter, J.H. Aktigraphie: Methodische Begrenzungen für die Beurteilung von Schlafstadien und Schlafstruktur gesunder Probanden [Actigraphy: Methodological limits for evaluation of sleep stages and sleep structure of healthy probands]. Pneumologie 1997, 51 (Suppl. 3), 721-724.

51. Ancoli-Israel, S.; Cole, R.; Alessi, C.; Chambers, M.; Moorcroft, W.; Pollak, C.P. The role of actigraphy in the study of sleep and circadian rhythms. Sleep 2003, 26, 342-392. [CrossRef]

52. Marino, M.; Li, Y.; Rueschman, M.N.; Winkelman, J.W.; Ellenbogen, J.M.; Solet, J.M.; Dulin, H.; Berkman, L.F.; Buxton, O.M. Measuring Sleep: Accuracy, Sensitivity, and Specificity of Wrist Actigraphy Compared to Polysomnography. Sleep 2013, 36, 1747-1755. [CrossRef]

53. Mayer, G.; Arzt, M.; Braumann, B. S3-Leitlinie Nicht erholsamer Schlaf/Schlafstörungen—Kapitel "Schlafbezogene Atmungsstörungen". Somnologie 2017, 20, 97-180. [CrossRef]

54. Andrade, L.; Paiva, T. Ambulatory Versus Laboratory Polysomnography in Obstructive Sleep Apnea: Comparative Assessment of Quality, Clinical Efficacy, Treatment Compliance, and Quality of Life. J. Clin. Sleep Med. 2018, 14, 1323-1331. [CrossRef]

55. Iber, C.; Redline, S.; Kaplan Gilpin, A.M.; Quan, S.F.; Zhang, L.; Gottlieb, D.J.; Rapoport, D.; Resnick, H.E.; Sanders, M.; Smith, P. Polysomnography performed in the unattended home versus the attended laboratory setting-Sleep Heart Health Study methodology. Sleep 2004, 27, 536-540. [CrossRef]

56. Miettinen, T.; Myllymaa, K.; Hukkanen, T.; Töyräs, J.; Sipilä, K.; Myllymaa, S. Home Polysomnography Reveals a First-Night Effect in Patients With Low Sleep Bruxism Activity. J. Clin. Sleep Med. 2018, 14, 1377-1386. [CrossRef] [PubMed]

57. Gupta, R. Gibt es Einen First Night Effect bei Ambulanter Polysomnographie? Eine Untersuchung an Fünfundzwanzig Schlafgesunden Probanden. Ph.D. Thesis, Rheinisch-Westfälische Technische Hochschule Aachen, Aachen, Germany, 2005.

58. Veauthier, C.; Piper, S.K.; Gaede, G.; Penzel, T.; Paul, F. The first night effect in multiple sclerosis patients undergoing home-based polysomnography. Nat. Sci. Sleep 2018, 10, 337-344. [CrossRef] [PubMed]

59. Schumann, A.; Kietzer, S.; Ebel, J.; Bär, K.J. Sympathetic and Parasympathetic Modulation of Pupillary Unrest. Front. Neurosci. 2020, 14, 178. [CrossRef] [PubMed]

60. Kelbsch, C.; Strasser, T.; Chen, Y.; Feigl, B.; Gamlin, P.D.; Kardon, R.; Peters, T.; Roecklein, K.A.; Steinhauer, S.R.; Szabadi, E.; et al. Standards in Pupillography. Front. Neurol. 2019, 10, 129. [CrossRef] [PubMed]

61. Boyne, K.; Sherry, D.D.; Gallagher, P.R.; Olsen, M.; Brooks, L.J. Accuracy of computer algorithms and the human eye in scoring actigraphy. Sleep Breath. 2013, 17, 411-417. [CrossRef] [PubMed]

62. Pougnet, R.; Pougnet, L.; Loddé, B.; Canals, L.; Bell, S.; Lucas, D.; Dewitte, J.D. Consumption of addictive substances in mariners. Int. Marit. Health 2014, 65, 199-204. [CrossRef] [PubMed]

63. Shahid, A.; Wilkinson, K.; Marcu, S.; Shapiro, C.M. STOP, THAT and One Hundred Other Sleep Scales; Springer Science \& Business Media: New York, NY, USA, 2012.

64. Tamura, Y.; Horiyasu, T.; Sano, Y.; Chonan, K.; Kawada, T.; Sasazawa, Y.; Kuroiwa, M.; Suzuki, S. Habituation of sleep to a ship's noise as determined by actigraphy and a sleep questionnaire. J. Sound Vib. 2002, 250, 107-113. [CrossRef]

65. DGAUM. S2k-Leitlinie Gesundheitliche Aspekte und Gestaltung von Nacht- und Schichtarbeit. Available online: https://www. awmf.org/uploads/tx_szleitlinien/002-0301_S2k_Gesundheitliche-Aspekte-Gestaltung-Nacht-und-Schichtarbeit_2020-03.pdf (accessed on 23 April 2021).

66. Arendt, J.; Middleton, B.; Williams, P.; Francis, G.; Luke, C. Sleep and circadian phase in a ship's crew. J. Biol. Rhythm. 2006, 21, 214-221. [CrossRef]

67. Oldenburg, M.; Jensen, H.J. Stress and strain among merchant seafarers differs across the three voyage episodes of port stay, river passage and sea passage. PLoS ONE 2019, 14, e0217904. [CrossRef]

68. Pigeon, W.R.; Taylor, M.; Bui, A.; Oleynk, C.; Walsh, P.; Bishop, T.M. Validation of the Sleep-Wake Scoring of a New Wrist-Worn Sleep Monitoring Device. J. Clin. Sleep Med. 2018, 14, 1057-1062. [CrossRef]

69. Quante, M.; Kaplan, E.R.; Cailler, M.; Rueschman, M.; Wang, R.; Weng, J.; Taveras, E.M.; Redline, S. Actigraphy-based sleep estimation in adolescents and adults: A comparison with polysomnography using two scoring algorithms. Nat. Sci. Sleep 2018, 10, 13-20. [CrossRef] [PubMed]

70. Rupp, T.L.; Balkin, T.J. Comparison of Motionlogger Watch and Actiwatch actigraphs to polysomnography for sleep/wake estimation in healthy young adults. Behav. Res. Methods 2011, 43, 1152-1160. [CrossRef] [PubMed] 